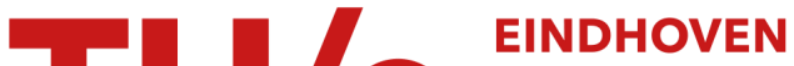 UNIVERSITY OF TECHNOLOGY
}

\section{Overload capability of linear flux switching permanent magnet machines}

\section{Citation for published version (APA):}

Amara, Y., Barakat, G., Paulides, J. J. H., \& Lomonova, E. (2013). Overload capability of linear flux switching permanent magnet machines. In Proceedings of the Ninth International Symposium on Linear Drives for Industry Applications (LDIA13), 7-10 July 2013, Hangzhou, China (pp. 345-352). (Applied Mechanics and Materials; Vol. 416-417). https://doi.org/10.4028/www.scientific.net/AMM.416-417.345

DOI:

10.4028/www.scientific.net/AMM.416-417.345

Document status and date:

Published: 01/01/2013

\section{Document Version:}

Publisher's PDF, also known as Version of Record (includes final page, issue and volume numbers)

\section{Please check the document version of this publication:}

- A submitted manuscript is the version of the article upon submission and before peer-review. There can be important differences between the submitted version and the official published version of record. People interested in the research are advised to contact the author for the final version of the publication, or visit the $\mathrm{DOI}$ to the publisher's website.

- The final author version and the galley proof are versions of the publication after peer review.

- The final published version features the final layout of the paper including the volume, issue and page numbers.

Link to publication

\section{General rights}

Copyright and moral rights for the publications made accessible in the public portal are retained by the authors and/or other copyright owners and it is a condition of accessing publications that users recognise and abide by the legal requirements associated with these rights.

- Users may download and print one copy of any publication from the public portal for the purpose of private study or research.

- You may not further distribute the material or use it for any profit-making activity or commercial gain

- You may freely distribute the URL identifying the publication in the public portal.

If the publication is distributed under the terms of Article $25 \mathrm{fa}$ of the Dutch Copyright Act, indicated by the "Taverne" license above, please follow below link for the End User Agreement:

www.tue.nl/taverne

Take down policy

If you believe that this document breaches copyright please contact us at:

openaccess@tue.nl

providing details and we will investigate your claim. 


\title{
Overload Capability of Linear Flux Switching Permanent Magnet Machines
}

\author{
Yacine Amara ${ }^{1 a}$, Georges Barakat ${ }^{1 b}$, Johan Paulides ${ }^{2 c}$, \\ and Elena Lomonova ${ }^{2 \mathrm{~d}}$ \\ ${ }^{1}$ GREAH, EA 3220, Université du Havre, Le Havre, France \\ ${ }^{2}$ Eindhoven University of Technology, Electromechanics and Power Electronics (EPE) Group, \\ The Netherlands \\ ayacine.amara@univ-lehavre.fr, ’georges.barakat@univ-lehavre.fr, cj.j.h.paulides@tue.nl, \\ de.lomonova@tue.nl
}

Keywords: Linear motor, overload capability, permanent magnet, switched flux.

\begin{abstract}
The 2D nature of magnetic field in permanent magnet flux-switching machines and the presence of all magnetic field sources [permanent magnets and windings (armature windings and eventually excitation coils)] in the stator, which implies a completely passive moving armature, makes them very good candidates in many different applications. Due to these interesting features, rotating and linear permanent magnet flux switching structures attracted considerable research efforts in the last years. However, to date, the overload capability of this kind of structures has not been investigated in detail. The study presented in this paper will help identify main factors limiting the improvement of overload capability for PM flux switching machines. Solutions to improve this characteristic will also be explored.
\end{abstract}

\section{Introduction}

Permanent magnet (PM) flux switching machine is one of the structures which attracted considerable research efforts, in the last years. The 2D nature of magnetic field in permanent magnet flux-switching machines and the presence of all magnetic field sources in the stator, which implies a completely passive moving armature, make them very good candidates in many different applications. Furthermore, flux focusing principal may be utilized and low-cost ferrite magnets may be employed (Fig. 1).

Different PM flux switching machines topologies, rotating and linear, have been investigated in scientific literature [1]-[16]. In references [1] to [8], rotating radial flux structures have been investigated. In [9], a rotating axial flux machine is analyzed. In references [10] to [16], different permanent magnet flux switching linear machines are examined.

Although different aspects related to the design of PM flux switching machines are investigated in these papers, to date, the overload capability of this kind of structures has not been investigated in detail. The study presented in this paper will help identify main factors limiting the improvement of overload capability for PM flux switching machines. Solutions to improve this characteristic will also be explored. Overload capabilities of PM flux switching linear machines are investigated by 2-D finite-element analyses.

Indeed, some applications, as accelerators for crash experiments, or as linear drives designed to move simulator domes for dynamic driving simulators, or as urban Maglev propulsion drives, require linear drives with high overload capabilities [17] [18]. It is then interesting to explore the possibility of using permanent magnet flux switching linear machines for this type of applications. 


\section{Overload capability of PM flux switching linear machines}

The overload capability of linear flux switching PM machines is assessed by comparing the performance of two structures: a flux switching PM structure (PMFSLM) (Fig. 1) [15] and a surface mounted PM structure (SPMLM) (Fig. 2). Performances of both structures are analyzed using finite element method (FE).

Figs. 1 and 2 show respectively the PMFSLM and SPMLM structures with the repartition of the three-phase windings. Main characteristics of both structures are given in Table I. Dimensions of the PMFSLM are taken from reference [15]. Dimensions of the SPMLM structure (Fig. 2) are directly derived from those of the PMFSLM structure. For flux switching machines the number of pole pairs corresponds to the number of moving armature teeth, i.e., 5 for the studied PMFSLM structure. The number of pole pairs is then identically set equal to 5 for the SPMLM structure. Both machines have same overall dimensions: same length, same height and same active length. Permanent magnet length, for the SPMLM structure, is calculated by dividing the machine axial length by the number of poles. The height of the magnets is calculated from total PM volume which is kept the same for both structures. Copper active volume is also kept the same for both structures. However, end-windings copper volume is lower for the SPMLM structure.

Fig. 3 shows the variation of thrust force with the maximum armature current density for both structures. FE calculations are done considering infinite long armatures, but the thrust calculation only concern one elementary cell (Figs. 1 and 2).

For each value of armature current, the maximum value of thrust force is sought. The imposed currents have sinusoidal waveforms. As can be seen, from Fig. 3, the thrust force is higher for the SPMLM machine, for high values of the current density, as compared to the PMFSLM machine. It has been noticed that while, for lower values of current density, the thrust force ripple to mean force ratio is lower for the SPMLM structure as compared to the PMFSLM structure, it becomes roughly comparable for higher values of current density.

Fig. 4 shows flux density magnitude distribution for both structures for a maximum current density of $100 \mathrm{~A} / \mathrm{mm}^{2}$, at a given position. Fig. 5 shows flux density magnitude distributions for both structures, in same conditions, for a variation range corresponding to the highly saturated part of the B-H curve of lamination steel.

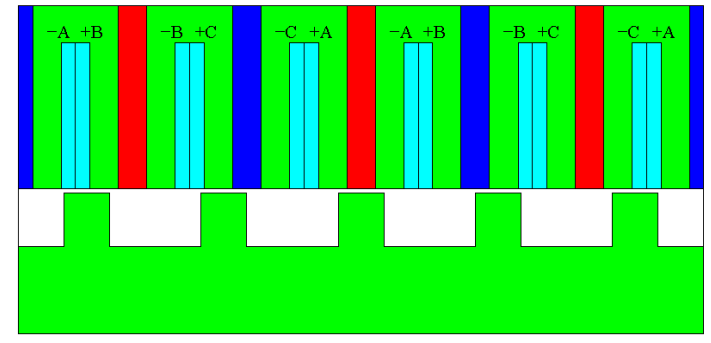

Fig. 1. PM flux-switching linear structure (PMFSLM) [15].

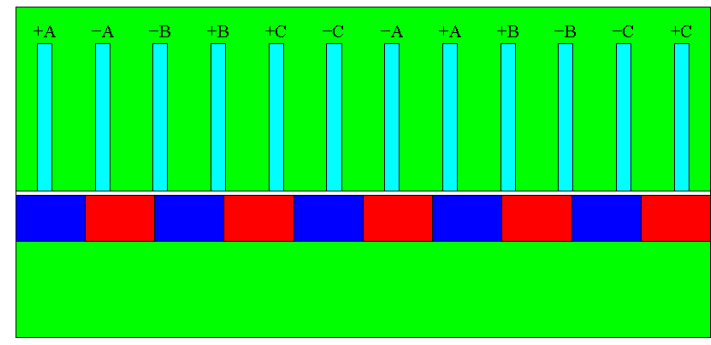

Fig. 2. Surface mounted PM linear structure (SPMLM).

TABLE I

LINEAR MACHINES DESIGN PARAMETERS

\begin{tabular}{|c|c|c|}
\hline Parameter & PMFSLM & SPMLM \\
\hline Magnet material & \multicolumn{2}{|c|}{$\mathrm{NdFeB}$} \\
\hline Magnet characteristics & \multicolumn{2}{|c|}{$\mathrm{Br}=1.2[\mathrm{~T}], \mu \mathrm{r}=1.034$} \\
\hline Steel lamination material & \multicolumn{2}{|c|}{ M330-35A } \\
\hline Air-gap length $(\mathrm{g})[\mathrm{mm}]$ & \multicolumn{2}{|c|}{0.5} \\
\hline Axial length (moving plane, $x$ direction) $(\mathrm{Lt})[\mathrm{mm}]$ & \multicolumn{2}{|c|}{78} \\
\hline Active length (z direction) $[\mathrm{mm}]$ & \multicolumn{2}{|c|}{60} \\
\hline
\end{tabular}




\begin{tabular}{|c|c|c|}
\hline Stator height (Hst) $[\mathrm{mm}]$ & \multicolumn{2}{|c|}{20.75} \\
\hline Slot height $(\mathrm{Hs})[\mathrm{mm}]$ & 3.28 & 1.64 \\
\hline Slot opening width $(\mathrm{Ws})[\mathrm{mm}]$ & 3.24 & 7.8 \\
\hline PM axial length (Wpm) $[\mathrm{mm}]$ & 20.75 & 5.17 \\
\hline PM height $(\mathrm{Hpm})[\mathrm{mm}]$ & \multicolumn{2}{|c|}{16} \\
\hline Moving armature total height $(\mathrm{Hm})[\mathrm{mm}]$ & 6.06 & \\
\hline Mover tooth height (PMFSLM) $(\mathrm{Hmt})[\mathrm{mm}]$ & 5.18 & \multicolumn{2}{|c|}{0.6} \\
\hline Mover tooth axial length (PMFSLM) $(\mathrm{Wmt})[\mathrm{mm}]$ & \multicolumn{2}{|c|}{16} \\
\hline Slot fill factor &
\end{tabular}

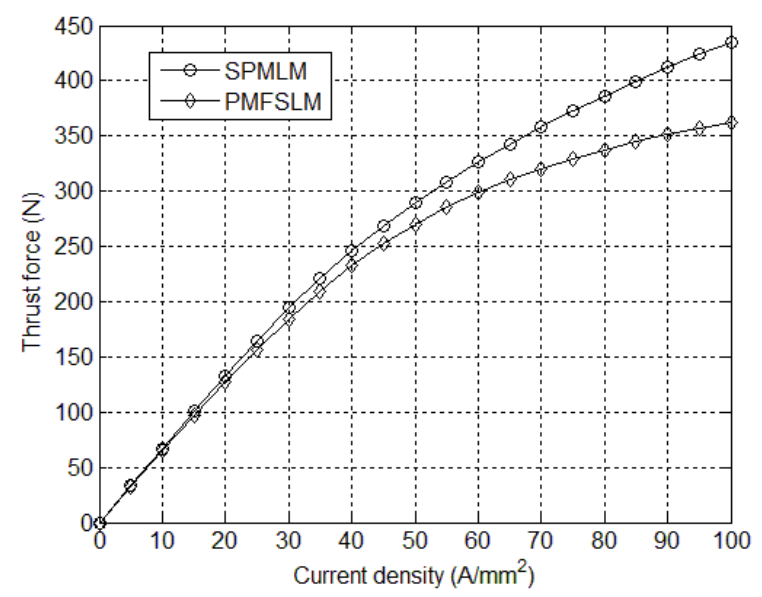

Fig. 3. Thrust force versus maximum armature current density.

It can be noticed from these two figures, that magnetic saturation is affecting more significantly the PMFSLM structure. Indeed, it can be seen, from Fig. 5, that the magnitude of flux density is higher in the PMFSLM structure as compared to the SPMLM structure. This is a consequence of the presence of all magnetic field sources in the stator, which implies a reduced volume for the stator iron core, and as a consequence a higher vulnerability to magnetic saturation effects.

The improving of PMFSLM structure overload capability can be reached by reducing magnetic saturation level, and its effects, even for high values of armature current density.

In following section, different tracks will be explored for the improvement of overload capability of the PMFSLM.

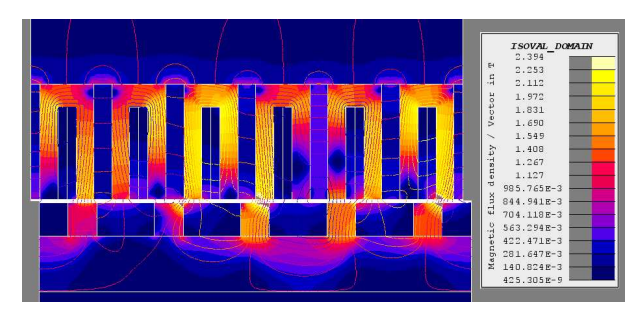

(a) PMFSLM

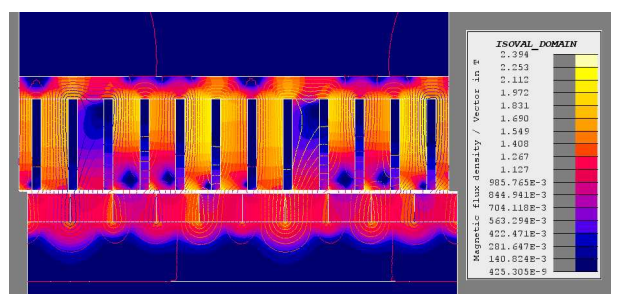

(b) SPMLM

Fig. 4. Flux density magnitude distribution in PMFSLM structure (a), and SPMLM structure (b), for a maximum current density of $100 \mathrm{~A} / \mathrm{mm}^{2}$. 


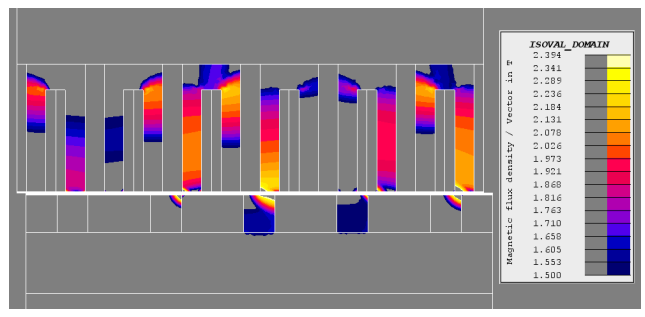

(a) PMFSLM

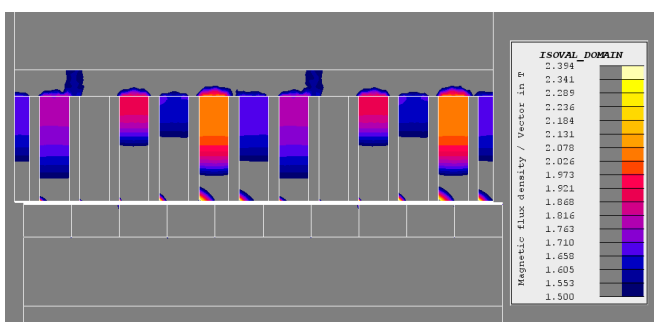

(b) SPMLM

Fig. 5. Flux density magnitude distribution in PMFSLM structure (a), and SPMLM structure (b), in highly saturated iron core regions.

\section{Improvement of the overload capability of the PMFSLM structure}

Different means to increase the overload capability of the PMFSLM structure will be explored in this section. The goal will be to try to reach same thrust force level as the SPMLM structure for a maximum current density of $100 \mathrm{~A} / \mathrm{mm}^{2}$. The improvement of overload capability of the PMFSLM structure will be sought first by increasing the permanent magnets volume. The second option will be to try to improve the overload capability by increasing the copper volume, and finally by increasing more specifically the iron core volume. More details are given in following subsections.

It should be noticed that in order to keep the same thrust force over a certain stroke, the stator or moving armature is always designed shorter or longer than the mover or the stator respectively. While for the PMFSLM structure, the passive part, which can be the mover or the stator, can be chosen as the longer part, for the SPMLM structure the longer part will necessarily contain whether copper or permanent magnets material. Off course, it will be preferable that the shorter part contain copper to save money. This fact constitutes an additional advantage for the PMFSLM structure, which helps to save expensive materials as compared to the SPMLM structure.

Increasing the Volume of Permanent Magnets. The increase of PM volume can be realized by increasing the axial length ( $\mathrm{x}$ direction) of the magnets or their height (y direction). While for the first option, the stator iron core volume can be maintained constant, it is necessarily increased if the height of the PM is increased $(\mathrm{Hst}=\mathrm{Hpm})$. Both options imply increasing the overall dimensions of the PMFSLM structure. The copper volume in the machine's active part is maintained constant. The adopted options will not help decrease the magnetic saturation level in the stator teeth, since axial length of these teeth $\mathrm{Wt}$ is maintained constant $(\mathrm{Wt}=3.24 \mathrm{~mm})$.

Fig. 6 compares thrust force waveforms, when the magnets axial length $\mathrm{Wpm}$ is respectively equal to $4 \mathrm{~mm}$ and $5.25 \mathrm{~mm}$, with the initial PMFSLM structure thrust force waveform. The PM height $\mathrm{Hpm}$ is maintained constant and equal to initial value $(\mathrm{Hpm}=20.75 \mathrm{~mm})$. It can be noticed that the thrust force mean value does not increase significantly and still lower than corresponding value from the SPMLM structure.

Fig. 7 compares thrust force waveforms, when the magnets height Hpm is respectively equal to $25 \mathrm{~mm}$ and $33 \mathrm{~mm}$, with the initial PMFSLM structure thrust force waveform. The PM axial length $\mathrm{Wpm}$ is maintained constant and equal to initial value $(\mathrm{Wpm}=3.28 \mathrm{~mm})$. Again, it can be noticed that the thrust force mean value does not increase significantly and still lower than corresponding value from the SPMLM structure. This is due to magnetic saturation which is still significantly important in stator iron core. 

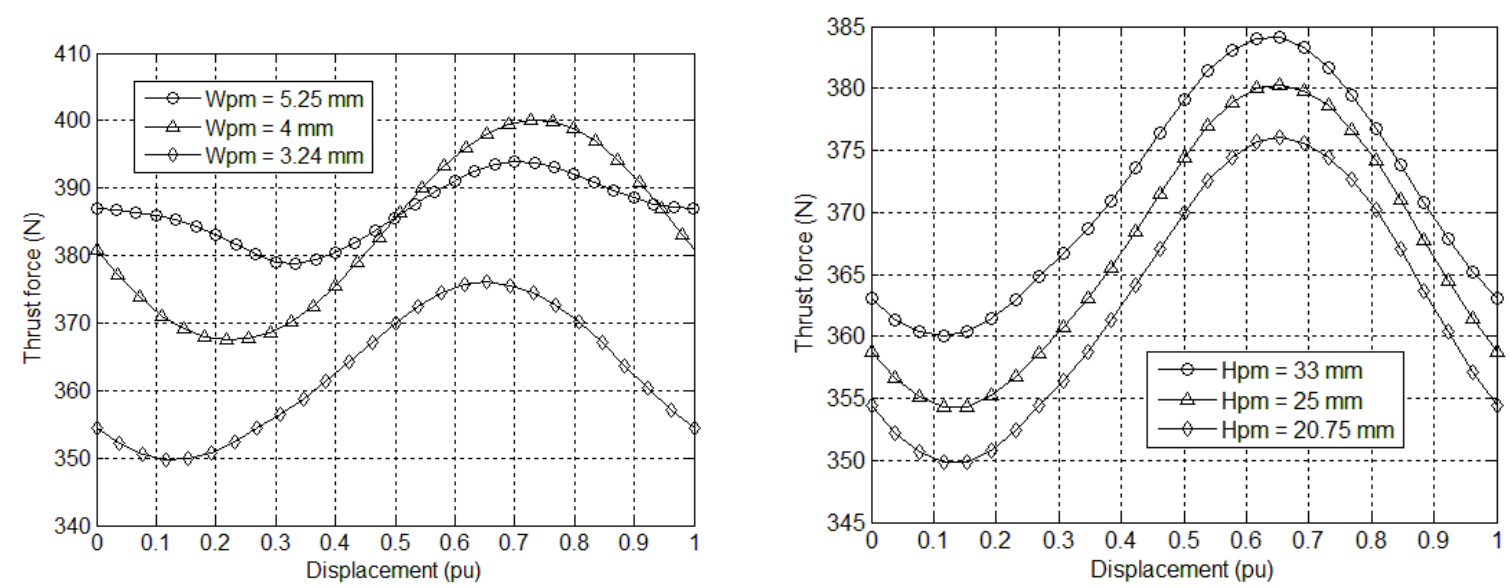

Fig. 6. Thrust force waveforms comparison (PMFSLM structure with different PM width Wpm, $\mathrm{J}_{\max }=100 \mathrm{~A} / \mathrm{mm}^{2}$ ).Fig. 7. Thrust force waveforms comparison (PMFSLM structure with different PM height Hpm, $\mathrm{J}_{\max }=100 \mathrm{~A} / \mathrm{mm}^{2}$ ).

It can also be noticed, from Figs. 5 and 6, that the increase of thrust force mean value is more effective when increasing the PM width as compared to the increase of PM height, for same PM volume.

Increasing the Volume of Copper. The increase of the copper volume is first sought by increasing the slot fill factor [19]. Fig. 8 compares thrust force waveforms for three different slot fill factors (slot fill factor $=0.6,0.7$ and 0.8 ). The slot fill factor can be increased by using rectangular section copper wires or by using pre-pressed windings [19].

As can be seen, the thrust force mean value is increased when the slot fill factor increases. However, it can be noticed that the thrust force mean value does not increase significantly and still lower than corresponding value from the SPMLM structure. As for the increase of PM volume, two other options are explored to study the effect of copper volume increase. Thus, the copper volume increase can be realized by increasing the slot area, whether by increasing the slot opening width or the slot height. The adopted options will not help decrease the magnetic saturation level in the stator teeth, since axial length of these teeth is maintained constant. The PM volume is kept constant and equal to that of the initial machine. The slot fill factor is also maintained constant and equal to 0.6.

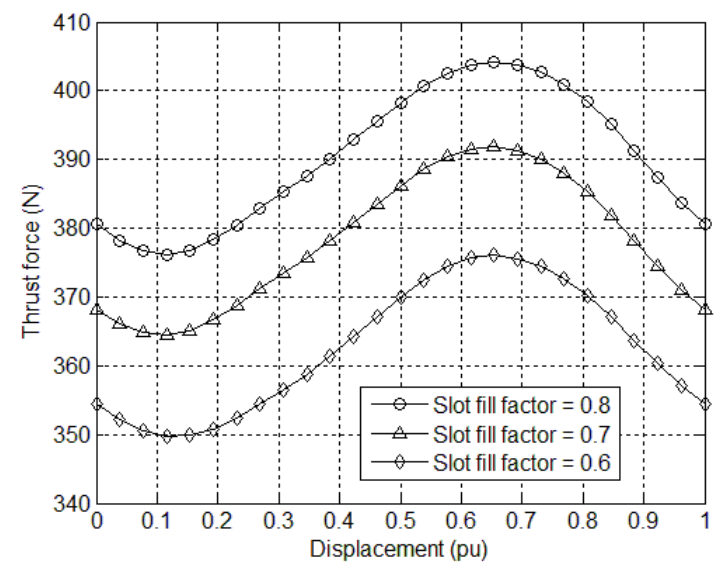

Fig. 8. Thrust force waveforms comparison (PMFSLM structure with different slot fill factor, $\mathrm{J}_{\max }=100 \mathrm{~A} / \mathrm{mm}^{2}$ ).

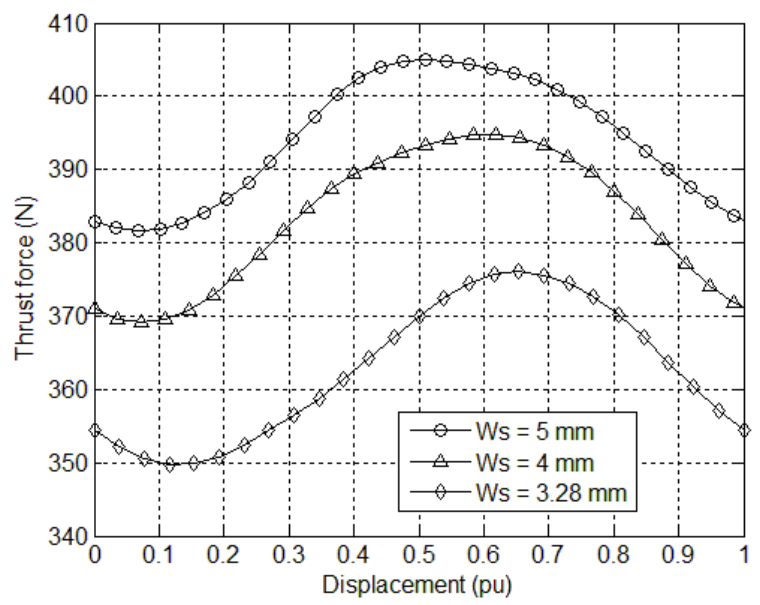

Fig. 9. Thrust force waveforms comparison (PMFSLM structure with different slot opening width Ws, $\mathrm{J}_{\max }=100 \mathrm{~A} / \mathrm{mm}^{2}$ ).

The increase of slot area by increasing its width (x direction) is first studied. Fig. 9 compares thrust force waveforms for three different slot width Ws values. As can be seen, the thrust force mean value is increased when the slot opening width increases. However, it can be noticed that the thrust force 
mean value still lower than corresponding value from the SPMLM structure, even for Ws $=5 \mathrm{~mm}$. The second option to increase the slot area is to increase its height Hs (y direction). This option implies a modification in machine structure, as can be seen from Fig. 10. Fig. 10 shows the machine with $\mathrm{Hs}=25.23 \mathrm{~mm}$. Fig. 11 compares thrust force waveforms for three different slot height Hs values. As compared to initial structure, the choice of a value of $\mathrm{Hs}=20.2 \mathrm{~mm}$ or $25.23 \mathrm{~mm}$ $(\mathrm{Ws}=3.28 \mathrm{~mm}$ ) will have same impact on the slot area as the choice of a value of $\mathrm{Ws}=4 \mathrm{~mm}$ or $5 \mathrm{~mm}(\mathrm{Hs}=16.55 \mathrm{~mm})$ respectively.

It can be noticed from Fig. 11, that it is pointless to increase the copper volume by increasing the slot height. Indeed, the mean value of thrust force, for high values of armature current density, is not really affected, when Hs is varying from $16.55 \mathrm{~mm}$ to $20.20 \mathrm{~mm}$ or $25.23 \mathrm{~mm}$.

Increasing the Volume of Iron Core. In previous options adopted to improve the overload capability, the dimensions of stator teeth have been kept invariant. The magnetic saturation, which essentially affects the stator teeth (Figs. 4 and 5), will then limit the effect of these measures in the improvement of overload capability.

In this section, the improvement of overload capability is sought by increasing the volume of stator iron core. The goal will be to reduce magnetic saturation in the stator teeth. To do so, the stator teeth width Wt is increased. Fig. 12 compares thrust force waveforms of the SPMLM structure, the initial PMFSLM structure $(\mathrm{Wt}=3.24 \mathrm{~mm})$, and finally the new PMFSLM structure $(\mathrm{Wt}=4.86 \mathrm{~mm})$.

The value of stator teeth width for the new PMFSLM structure is calculated by keeping same stator iron core volume as the SPMLM structure. PM and slot dimensions are kept invariant compared to initial PMFSLM structure. Of course, the total axial length $\mathrm{Lt}$ is modified $(\mathrm{Lt}=97.44 \mathrm{~mm})$. The pole pitch will also be affected. However, dimensions of rotor teeth are kept invariant as compared to initial PMFSLM structure.
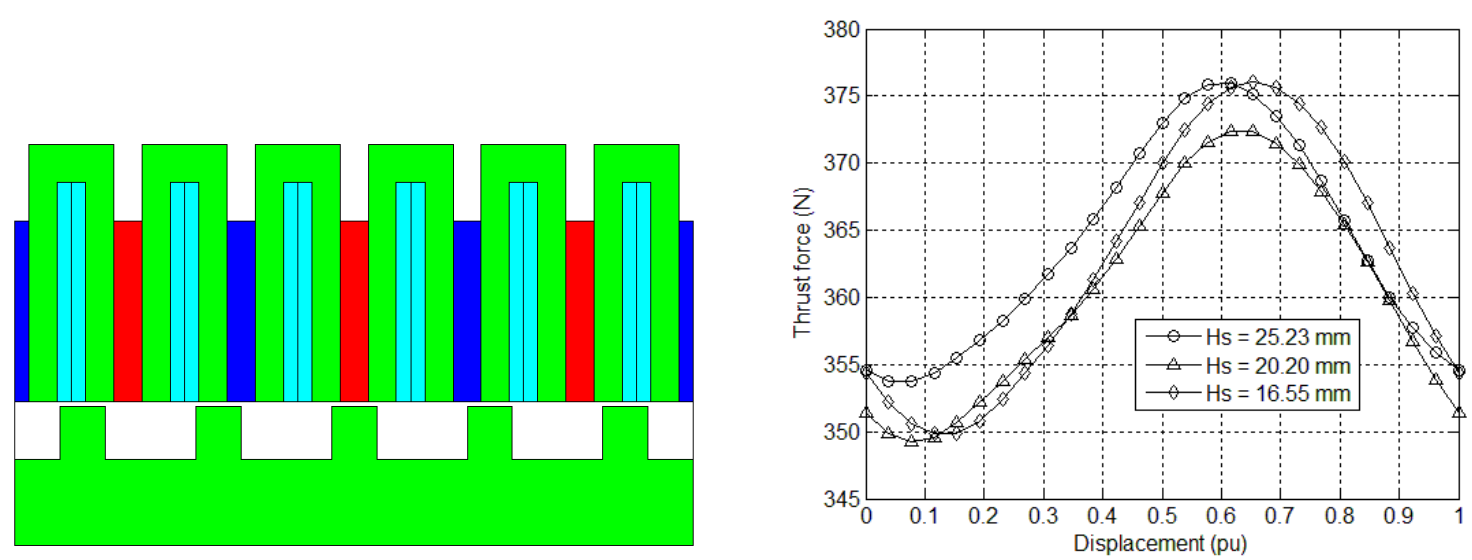

Fig. 10. PMFSLM structure with $\mathrm{Hs}=25.23 \mathrm{~mm}$. Fig. 11. Thrust force waveforms comparison (PMFSLM structure with different slot height Hs, $\mathrm{J}_{\max }=100 \mathrm{~A} / \mathrm{mm}^{2}$ ).

From Fig. 12, it can be noticed that thrust force mean value is significantly increased. Increasing the stator teeth width to reduce magnetic saturation level is then the most effective way to improve the overload capability. Due to the increase of slot pitch $(\mathrm{Lt}=97.44 \mathrm{~mm})$, the armature end windings volume will also increase. Nevertheless, as explained at the beginning of this section, in order to keep the same thrust force over a certain stroke, SPMLM structure may need extra copper or PM material as compared to PMFSLM structure. 


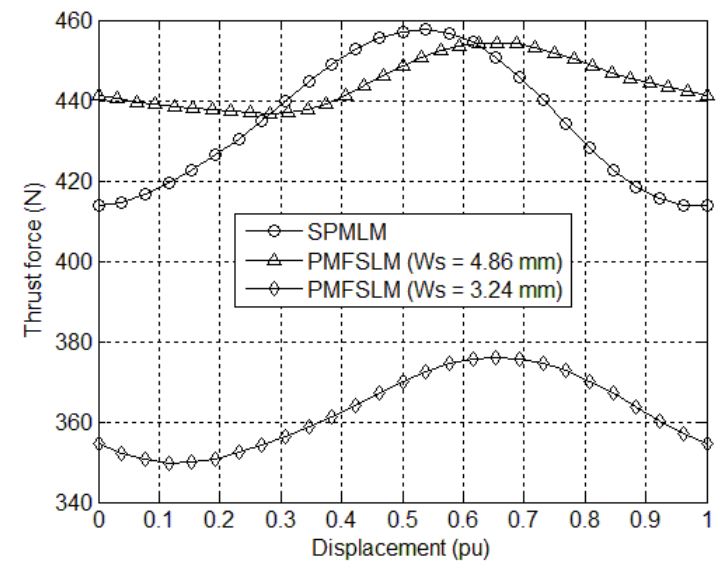

Fig. 12. Thrust force waveforms comparison $\left(\mathrm{J}_{\max }=100 \mathrm{~A} / \mathrm{mm}^{2}\right)$.

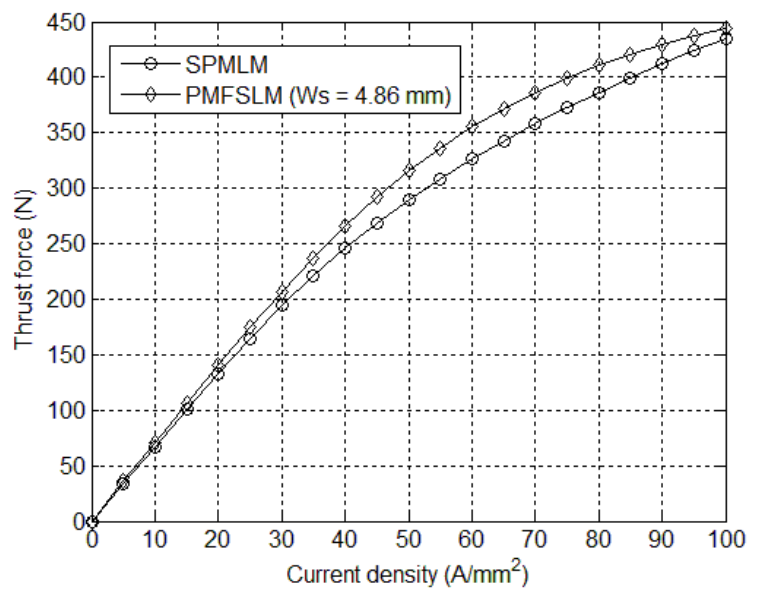

Fig. 13. Thrust force versus maximum armature current density.

The improvement of PMFSLM structure's overload capability may then be obtained without extra charges as compared to the SPMLM structure. Fig. 13 compares the variation of thrust force with the maximum armature current density for the SPMLM structure and the new PMFSLM structure $(\mathrm{Wt}=4.86 \mathrm{~mm})$.

\section{Conclusion}

The presence of all magnetic field sources in the same armature (stator or mobile armatures), which is the case of PMFSLM machines, impact negatively the overload capability of these electrical machines. Indeed, having all magnetic field sources in same armature accentuate the effects of magnetic saturation, which limits the thrust force production.

Different solutions to improve the overload capability of a PMFSLM structure have been explored. It was found that the increase of the iron core of the armature containing magnetic field sources, in order to reduce magnetic saturation level, is the more effective way to improve the overload capability.

\section{References}

[1] E. Hoang, A. H. Ben-Ahmed, and J. Lucidarme, "Switching flux PM polyphased synchronous machines," in Proc. 7th Eur. Conf. Power Electron. Appl., 1997, vol. 3, pp. 903-908.

[2] Z. Q. Zhu, and J. T. Chen, "Advanced flux-switching permanent magnet brushless machines," IEEE Trans. Magn., Vol. 46, No. 6, pp. 1447-1453, June 2010.

[3] R. L. Owen, Z. Q. Zhu, A. S. Thomas, G. W. Jewell, and D. Howe, "Alternate poles wound flux-switching permanent-magnet brushless AC machines," IEEE Trans. Ind. Appl., Vol. 46, No. 2, pp. 790-797, March/April 2010.

[4] E. Ilhan, B. L. J. Gysen, J. J. H. Paulides, and E. A. Lomonova, “Analytical hybrid model for flux switching permanent magnet machines," IEEE Trans. Magn., Vol. 46, No. 6, pp. 1762-1765, June 2010.

[5] J. T. Chen, and Z. Q. Zhu, "Comparison of all- and alternate-poles-wound flux-switching PM machines having different stator and rotor pole numbers," IEEE Trans. Ind. Appl., Vol. 46, No. 4, pp. 1406-1415, July/August 2010.

[6] J. T. Chen, Z. Q. Zhu, S. Iwasaki, and R. P. Deodhar, "A novel E-core switched-flux PM brushless AC Machine,” IEEE Trans. Ind. Appl., Vol. 47, No. 3, pp. 1273-1282, May/June 2011. 
[7] E. Sulaiman, T. Kosaka, and N. Matsui, "High power density design of 6-slot-8-pole hybrid excitation flux switching machine for hybrid electric vehicles," IEEE Trans. Magn., Vol. 47, No. 10, pp. 4453-4456, October 2011.

[8] J. Ojeda, M. G. Simões, G. Li, and M. Gabsi, "Design of a flux-switching electrical generator for wind turbine systems," IEEE Trans. Ind. Appl., Vol. 48, No. 6, pp. 1808-1816, Nov./Dec. 2012.

[9] L. Hao, M. Lin , X. Zhao , X. Fu , Z.Q. Zhu , and P. Jin, "Static characteristics analysis and experimental study of a novel axial field flux-switching permanent magnet generator," IEEE Trans. Magn., Vol. 48, No. 11, pp. 4212-4215, Nov. 2012.

[10] J. Wang, W. Wang, K. Atallah, and D. Howe, "Design considerations for tubular flux-switching permanent magnet machines," IEEE Trans. Magn., Vol. 44, No. 11, pp. 4026-4032, Nov. 2008.

[11]C. F. Wang, J. X. Shen, Y. Wang, L. L. Wang, and M. J. Jin, "A new method for reduction of detent force in permanent magnet flux-switching linear motors," IEEE Trans. Magn., Vol. 45, No. 6, pp. 2843-2846, June 2009.

[12] M. J. Jin, C. F. Wang, J. X. Shen, and B. Xia, "A modular permanent-magnet flux-switching linear machine with fault-tolerant capability," IEEE Trans. Magn., Vol. 45, No. 8, pp. 3179-3186, August 2009.

[13]L. Huang, H. Yu, M. Hu, J. Zhao, and Z. Cheng, "A novel flux-switching permanent-magnet linear generator for wave energy extraction application," IEEE Trans. Magn., Vol. 47, No. 5, pp. 1034-1037, May 2011.

[14] W. Min, J. T. Chen, Z. Q. Zhu, Y. Zhu, M. Zhang, and G. H. Duan, "Optimization and comparison of novel E-core and C-core linear switched flux PM machines," IEEE Trans. Magn., Vol. 47, No. 8, pp. 2134-2141, August 2011.

[15]C. F. Wang and J. X. Shen, "A method to segregate detent force components in permanent-magnet flux-switching linear machines," IEEE Trans. Magn., Vol. 48, No. 5, pp. 1948-1955, May 2012.

[16] C. C. Hwang, P. L. Li , and C. T. Liu, "Design and analysis of a novel hybrid excited linear flux switching permanent magnet motor," IEEE Trans. Magn., Vol. 48, No. 11, pp. 2969-2972, Nov. 2012.

[17] K. Kim, "Design of the linear synchronous motor for general atomics urban MAGLEV system," in Proc. LDIA 2003, Birmingham, UK, 8-10 September 2003, pp. A5-A8.

[18] W. R. Canders, P. Hoffmann, H. Mosebach and G. Tareilus, "Large high performance linear drive with high overload capability and very small thrust ripple," in Proc.LDIA 2007, Lille, France, 16-19 September 2007, pp. 1-4.

[19] G. Jack, B. C. Mecrow, P. G. Dickinson, D. Stephenson, J. S. Burdess, N. Fawcett, and J. T. Evans, "Permanent-magnet machines with powdered iron cores and prepressed windings," IEEE Trans. Ind. Appl., Vol. 36, No. 4, pp. 1077-1084, July/August 2000. 
Linear Drives for Industry Applications IX

10.4028/www.scientific.net/AMM.416-417

Overload Capability of Linear Flux Switching Permanent Magnet Machines

10.4028/www.scientific.net/AMM.416-417.345 